PENGARUH JENIS MUSIK KLASIK YANG LEMBUT TERHADAP PERKEMBANGAN BAYI amilatul Fadliyah dan Irwansyah

MENGIDENTIFIKASI POTENSI SEJAK DINI PADA MASA ANAK-ANAK AWAL Fahrul Hidayat dan Zumtoatun Nangimah

EFEK NEGATIF FACEBOOK BAGI ANAK SEKOLAH DASAR (SD) Nur Azizah dan Ahmad Muhaimir

PERKEMBANGAN PSIKOLOGIS REMAJA DALAM MENENTUKAN PERSONAL IDENTITY

$$
\text { Indah Daratista dan Astuti Rahma }
$$

KESIAPAN MENTAL MAHASISWA DALAM MENUJU JENJANG PERNIKAHAN Afitasari Anggraini dan Arisatul Maulana

KECEMASAN WANITA DEWASA DALAM MENYIKAPI PENUAAN YANG DIALAMINYA Siti Badriatul Jannah dan Lidi Hardiansyah

MENGURANGI KECEMASAN LANSIA TENTANG GAMBARAN KEMATIAN DENGAN CARA RELIGIUS Dona Damara dan Yazid Asrori

Penerbit Wali songo Sukajadi

\title{
KOMPILAS MAKALAH
}

Perkembangan Manusia Sepanjang Hayat

Penerbit Wali Songo Sukajadi

Karya tulis ini berada dibawah lisensi CC-BY-SA Anda dapat menggunakan semua konten dengan memberikan kredit yang pantas pada karya tulis ini.
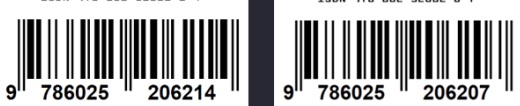

EDITOR: APREZO PARDODI MABA 


\section{KOMPILASI MAKALAH: PERKEMBANGAN MANUSIA SEPANJANG HAYAT}

Editor: Aprezo Pardodi Maba

Penerbit

Wali Songo Sukajadi 
Wali Songo Sukajadi

Lampung Tengah, Lampung Indonesia
Telp: +625381066661

Web: walisongosukajadi.com

Email: walisongo133@gmail.com

(C) 2018 by Wali Songo Sukajadi

Electronic International Standard Book Number: 978-602-52062-0-7

Print International Standard Book Number: 978-602-52062-1-4

\section{Judul:}

Kompilasi Makalah: Perkembangan Manusia Sepanjang Hayat

\section{Editor:}

Aprezo Pardodi Maba

\section{Reviewer:}

Dwi Bhakti Indri M.

Linda Dwi Sholikhah

Ma'rifatin Indah Kholili

Kushendar

Rikas Saputra

Hartika Utami Fitri

\section{Layout:}

Ahmad Mukhlishin

Karya tulis ini berada dibawah lisensi:

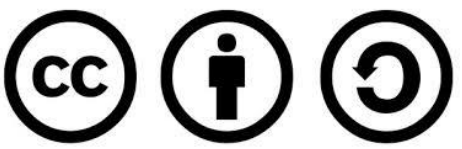

Anda dapat menggunakan semua konten dengan memberikan kredit yang pantas pada karya tulis ini. 


\section{KATA PENGANTAR}

Segala puji kami panjatkan kepada Allah SWT yang Maha Pengasih lagi Maha Penyayang. Sholawat serta salam semoga tetap terlimpahkan kepada junjungan kita Nabi Besar Muhammad SAW beserta sahabat, keluarga dan kaum muslimin yang telah berjuang meninggikan kebesaran-Nya.

Tidak ada yang patut diucapkan oleh kami selain ungkapan syukur yang sedalam-dalamnya karena telah diberikan kekuatan dan kesempatan menyelesaikan KOMPILASI

MAKALAH: PERKEMBANGAN MANUSIA SEPANJANG HAYAT, meskipun telah melewati proses review dan revisi tentunya masih banyak kekurangan dan masih banyak ruang yang menganga untuk perbaikan.

Buku ini disusun dimaksudkan untuk dapat dipergunakan sebagai bahan acuan atau referensi dan memudahkan bagi para mahasiswa dalam mengikuti perkulihan Psikologi Perkembangan, yang pada akhirnya dapat membantu kelancaran perkuliahan tersebut.

Kami mengucapkan terimakasih kepada tim reviewer karena telah meluangkan waktunya yang berharga untuk memberikan masukan-masukan agar makalah yang disusun dalam buku ini dapat diterbitkan dengan substansi terbaiknya. Kepada tim penulis, yang merupakan Mahasiswa Bimbingan dan Konseling Islam, Institut Agama Islam Ma'arif NU (IAIMNU) Metro Lampung, kami juga ucapkan terima kasih karena telah berkomitmen, kerja keras dan bersungguh-sungguh dalam menulis, merevisi dan mempresentasikannya di forum SEMINAR MATA KULIAH PSIKOLOGI PERKEMBANGAN.

Terakhir, editor berharap forum-forum dan kegiatan semacam ini dapat di lestarikan, khususnya di Institut Agama Islam Ma'arif NU (IAIMNU) Metro Lampung, sehingga dapat mengasah keterampilan menulis karya ilmiah dan berbicara didepan umum mahasiswa.

Metro, 07 Mei 2018

Editor 



\section{DAFTAR ISI}

HALAMAN JUDUL

HALAMAN PENERBIT

KATA PENGANTAR

DAFTAR ISI

PENGARUH JENIS MUSIK KLASIK YANG LEMBUT

TERHADAP PERKEMBANGAN BAYI

Jamilatul Fadliyah dan Irwansyah

MENGIDENTIFIKASI POTENSI SEJAK DINI PADA

MASA ANAK-ANAK AWAL

Fahrul Hidayat dan Zumroatun Nangimah

EFEK NEGATIF FACEBOOK BAGI ANAK SEKOLAH

DASAR (SD)

Nur Azizah dan Ahmad Muhaimin

PERKEMBANGAN PSIKOLOGIS REMAJA

DALAM MENENTUKAN PERSONAL IDENTITY YANG BAIK

Astuti Rahma dan Indah Daratista

KESIAPAN MENTAL MAHASISWA DALAM MENUJU JENJANG PERNIKAHAN

Afitasari Anggraini dan Arisatul Maulana

KECEMASAN WANITA DEWASA DALAM MENYIKAPI PENUAAN YANG DIALAMINYA

Siti Badriatul Janah dan Lidi Hardiansyah

MENGURANGI KECEMASAN LANSIA TENTANG GAMBARAN KEMATIAN DENGAN CARA RELIGIUS Dona Damara dan Yazid Asrori 



\title{
PENGARUH JENIS MUSIK KLASIK YANG LEMBUT TERHADAP PERKEMBANGAN BAYI
}

Jamilatul Fadliyah* \& Irwansyah

Jamilatulfadliyah03@gmail.com*

\begin{abstract}
Abstrak
Didalam musik klasik terdapat perananan yang sangat penting terhadap proses perkembangan bayi. Bayi yang selalu dibiasakan mendengarkan musik akan berintraksi sangat aktif di banding bayi yang jarang didengarkan oleh musik. Musik sangatlah baik untuk melatih kecerdasan bayi. Dalam hal ini musik sangat dihubungkan dalam pengalaman emosi yang mana musik klasik sngatlah berhubungan dengan kecerdasan bayi. Kecerdasan emosional merupakan salah satu kecerdasan yang paling penting bagi manusia yang seharusnya terus dilatih, dikelola, dan dikembangkan. Orang tua sangatlah berperan sekali terhadap perkembangan bayi. Seorang ibu harus mengetahu bagaimana tahap perkembangan bayi yang masih didalam kandungan hingga lahir. Sehingga bayi dapat berintraksi dan memiliki respon yang aktif terhadap lingkungannya.

Kata Kunci : musik klasik, berintraksi, orang tua, perkembangan bayi.
\end{abstract}

\section{A. Pendahuluan}

Pada masa perkembanga bayi, di butuhkannya suatu proses untuk menjadikan seorang bayi mengalami suatu perkembangan. Dalam hal ini sebagai sosok seorang ibu sangatlah berperan penting. Berbagai kehidupan dalam sehari-hari musik adalah contoh salah satu perkembangan yang mana dapat di kembangkan dalam berbagai proses perkembangan bayi.

Pada dasarnya manusia telah menyadari adanya manfaat terhadap getaran, irama, dan bunyi. Ada keyakinan didalam musik klasik bahwa musik klasik memiliki kekuatan untuk mempengaruhi jiwa. Hingga kini musik masih berperan dalam kehidupan manusia. Sehingga musik memiliki kekuatan yang luar biasa bagi perkembangan bayi.

Dalam proses perkembangan otak dan pikiran seorang bayi, ada sistem yang terbentuk pada tahap yang sangat dini, yakni sistem pendengaran. Telinga adalah sistem utama yang terhubung pada 
syaraf otak. Musik juga mampu menciptakan kemampuan berbahasa sang bayi terhadap intraksi yang didengarnya oleh bayi.

Sejalan dengan pandangan para cendikiawan Hindu Kuno yang berpendapat bahwa alam semesta muncul pada awalnya berupa bunyi, selanjutnya bunyi menjadi cahaya, dan cahaya menjadi dzat. Sebagaimana bekerjanya otak seorang bayi ketika musik mempengaruhi terhadap pendengarannya.

Pemberian musik klasik terhadap bayi secara rutin dapat menjadikan motorik yang tadinya tidak seimbang menjadikan motorik bayi yang lebih baik. Musik klasik sangat memberikan perkembangan yang cukup baik terhap motorik bayi. Adapun tujuan penulisan makalah ini adalah menjelaskan pengertian dari musik klasik, menjelaskan bagaimana reaksi seorang bayi ketika ia mendengarkan musik klasik dan menjelaskan perkembangan bayi yang dipengaruhi oleh musik.

\section{B. Kajian Teoritik}

Menurut Johanna Natalia di Universitas Surabaya, Fakultas Psikologi oleh Nelly Oktora meneliti bayi yang baru lahir secara normal, berusia 2 minggu- 4 bulan menurutnya bayi yang selalu mendengarkan musik klasik tingkat emosionalnya lebih stabil dari pada bayi yang tidak mendengarkannya. Pemberian musik klasik terhadap bayi dapat terlihat dari tingkah laku, dan intraksi bayi. ${ }^{1}$

Pemberian musik klasik terhadap bayi secara rutin dapat menjadikan motorik yang tadinya tidak seimbang menjadikan motorik bayi yang lebih baik. Musik klasik sangat memberikan perkembangan yang cukup baik terhap motorik bayi.

\section{Pembahasan \\ Pengertian Musik Klasik}

Musik adalah suatu ilmu pengetahuan dan suatu seni yang berupa melodi yang mana terdapat ungkapan rasa dalam diri manusia dalam sebuah bentuk pemikiran yang mana menghasilkan nada-nada atau berupa bunyi yang dapat dikenal oleh diri sendiri maupun orang lain didalam lingkungan sehari-hari yang dirasakan.

Musik klasik berasal dari Benua Eropa yang mana pada umumnya lebih sering disebut musik barat. Kata-kata klasik mulai

1 Nelly Octora dan Setiasih, "Pengaruh Musik Klasik terhadap Emosi Bayi yang Kehadirannya Tidak Diharapkan oleh Orang Tuanya" (Temu IImiah Nasional \& Kongres IX Himpsi, Surabaya, Januari 2004), http://repository.ubaya.ac.id/21413/. 
muncul pada abad ke-18, yang mana pada waktu itu terdapat suatu nilai-nilai berupa klasik yang diperoleh dari bangsa Yunani Kuno. Pada masa itu terdapat tiga tokoh yang sangatlah terkenal yaitu Mozart, Haydn, dan Beethoven. ${ }^{2}$

Didalam musik klasik terdapat intonasi nada yang terdiri dari intonasi-intonasi yang diantaranya nada tinggi dan nada rendah yang akan merangsang terhadap otak. Musik sangatlah mempengaruh didalam perkembangan pada otak sibayi. Musik terdapat tiga bagian yang sangat penting, diantaranya yaitu terdiri dari beat, ritme, dan harmony. Beat yaitu mempengaruhi tubuh, ritme yaitu mempengaruhi jiwa, dan harmony yaitu mempengaruhi roh.

Menurut Dr. Frank Wood, kepala bagian Neuro Psikologi di Bowman Gry School Of Madicine musik adalah suatu pokok utama bahasa otak. Maka untuk memungsikannya kembali kita diharuskan mengatur suasana ketentraman yang telah dirasakan oleh otak dan pikiran.

Adapun unsur-unsur musik secara umum ialah sebagai berikut: 1) suara, suara ialah suatu perubahan getaran pada udara. Didalam musik terdapat suatu glombang udara yang umumnya dibahas dalam panjang glombangnya ataupun priodenya. Di dalam unsur dasar suara yang ada didalam musik terdapat penjelasan yaitu yang berupa tala yakni suatu tinggi nada, durasi yakni berupa beberapa lama suara ada, intensitas dan timbre yakni berupa warna bunyi; 2) nada, nada yaitu suatu bagian suara dalam frekuensi tertentu. Nada dapat diatur dalam ferekuensi tertentu yang di bagi-bagi didalam tinggi nada terhadan nada patokan; 3) ritme atau irama, ritme ialah bunyi yang diatur didalam waktu. Irama suatau pembagian pembentukkan kelompok ketukan dalam waktu; 4) Melodi, melodi ialah sebuah rangkaian nada yang ada di dalam waktu; 5) harmoni, harmoni ialah proses kejadian nada yang terdiri dari beberapa nada dengan tinggi yang berbeda namun dibunyikan dengan bersamaan; 6) notasi, notasi yaitu notasi musik yang melalui gambaran yang berupa tulisan atas musik. Didalam sebuah notasi balok, tinggi dalam nada digambarkan berbentuk vertikal

2 Novian Gangga Kurniawan, "Efektivitas Musik Klasik (Mozart) untuk Menurunkan Kejenuhan Belajar Siswa Kelas Xi SMAN 4 Yogyakarta," Jurnal Riset Mahasiswa Bimbingan Dan Konseling 5, no. $\quad 7 \quad 12 \quad$ Oktober http://journal.student.uny.ac.id/ojs/ojs/index.php/fipbk/article/view/4036. 
atau keatas sedangkan waktu digambarkan berbentuk horizontal atau menyamping. ${ }^{3}$

\section{Pengaruh Musik Klasik}

Pada setiap manusia khususnya terhadap bayi atau anak usia dini sangatlah membutuhkan hal-hal yang baru, tetapi dalam hal ini sangatlah renta terhadap pengaruh perkembangan yang ada didalam lingkungan sekitarnya. Pada masa usia bayi banyak sekali proses yang memicu terhadap perkembangan kecerdasan emosional bayi.

Teori kognitif menyimpulkan bahwa dalam sekema kognitif dapat aktif saat mendengar dan mempengaruhi bagaimana reaksi otak terhadap musik. Dilihat dari aspek kognitif dan aktifitas otak bahwa dari separuh dari otak manusia memiliki tugas untuk memperoses berbagai aspek pengalaman musik. Dalam hal ini musik sangat dihubungkan dalam pengalaman emosi yang mana musik klasik sngatlah berhubungan dengan kecerdasan bayi.

Kecerdasan emosional dan intelegensi dari seorang bayi akan lebih berkembang jika terbiasa mendengar musik, dibandingkan bayi yang jarang sekali didengarkan oleh musik. Yang dimaksud musik disiini yaitu musik yang memiliki sebuah irama atau nada yang teratur. Sikap bayi juga sangat dipengaruhi oleh musik.

Dasar-dasar yang secara umum terdapat didalam musik klasik yang asalnya diperoleh dari ritme denyut nadi manusia sehingga didalamnya sangatlah berperan sekali dalam suatu prosesperkembangan otak, karakter, pembentukan jiwa, bahkan raga manusia. Oleh karenanya bayi yang lebih sering sekali mendengarkan sebuah musik dapat memiliki perkembangan yang aktif dibanding bayi yang sangat jarang sekali mendengarkan berbagai musik. ${ }^{4}$

Bayi dapat di beri stimulasi eksternal dengan mendengarkan musik. Jenis-jenis dari berbagai musik klasik atau musik yang bernada lembut cenderung di sukai oleh bayi dari pada musik yang keras, rock atau metalika. Menurut Monty Satiadarma berpendapat yakni musik klasik sangatlah dapat memberi rangsangan untuk meningkatkan

${ }^{3}$ Saifaturrahmi Hidaya, "Pengaruh Musik Klasik Terhadap Daya Tahan Konsentrasi dalam Belajar" (Universitas Islam Negeri Sultan Syarif Kasim Riau, 2011).

4 Siti Ngalifah, "Pengaruh Musik Klasik Terhadap Kecerdasan Emosional Anak Di TK Kemala Bhayangkari 06 Glondong Tirtomartani Kalasan Sleman Yogyakarta Tahun Ajaran 2009/2010," Skripsi). Yogyakarta: UIN Sunan Kalijaga, dalam http://digilib. uin-suka. ac. id. Diakses pada 25 (2010). 
kecerdasan emosional (emotional intelegence) maupun kecerdasan intelektual pada anak. Nada-nada musik klasik cenderung dapat memberi ketenangan, rasa aman dan membangkitkan daya imajenasi pada anak. ${ }^{5}$ Musik klasik juga dapat menciptakan kondisi jiwa dan fisik yang nyaman ataupun rileks. Dengan kondisi yang dialami seperti itu sangatlah berreaksi untuk mendapatkan daya kecerdasan bayi yang kuat.

Didalam musik klasik juga banyak berbagai manfaat diantaranya yaitu musik dapat mempengaruhi salah satu ketegangan otot dan dapat memperbaiki motorik atau gerak beserta kordinasi tubuh, musik dapat mempengaruhi badan yang memiliki suhu yang tidak teratur, musik dapat meningkatkan suatu daya tahan tubuh terhadap bayi, dan masih banyak sekali manfaat yang dipengaruhi oleh musik terhadap perkembangan bayi. ${ }^{6}$

\section{Perkembangan Bayi}

Menurut Piaget bayi belum bisa menampilkan kepemilikan citra mental atau keterampilan simbolik, tetapi bayi dapat berfokus pada gerakan fisiknya. Pada permulaan sensorimotor, pikiran bayi berdasarkan pada tindakan atau gerak-gerik fisiknya. Bayi melakukan sensorimotor dengan secara kualitatif. Adapun periode perkembangan bayi diantaranya yaitu:

\section{Periode Pralinguistik}

Periode pralinguistik ini adalah masa dimana seorang anak sebelum mengenal bahasa. Ketika bayi mulai tumbuh kembang, bayi mengembangkan bahasanya melalui tahapan-tahapan. Tahapan Pertama, ketika lahirnya bayi sampai berusia dua bulan yaitu ada masa fonasi. Pada saat itu bayi sering sekali menciptakan sesuatu yang disebut "bunyi-bunyi yang menyenangkan". Ketika itu bunyi-bunyi tersebut dinamakan "quasi vowel'. Disebut dengan quasi karena suara yang keluar tidak sepenuhnya dan sebanyak suara vokal yang diciptakan setelah berikutnya. Suara vokal diciptakan dari suara yang sama pada yang pertama. Pada antara usia 2 dan 4 bulan, bayi umumnyaada padagoing stage, yaitu bayi yang sudah bisa

${ }^{5}$ Agoes Dariyo, Psikologi Perkembangan Anak Tiga Tahun (Bandung: Pertama, PT Refika Aditama, 2007).

${ }^{6}$ Dina Mutiah Larasati, "Pengaruh Terapi Musik terhadap Tingkat Kecemasan Sebelum Bertanding pada Atlet Futsal Putri Tim Muara Enim Unyted," 2017. 
mengucapkan kata yang sama dengan kata yang berkombinasi quasi vokal dengan keras, sebagai tanda permulaan konsonan. Antara 4 dan 7 bulan anak mampu menciptakan beberapa kata yang baru, disebut dengan masa expansion stage. Tahap kedua, sesudah anak telah belajar mengeluarkan beberapa suara dalam sebuah bentuk tangisan, anak akan mulai mengoceh. Bunyi atau suara yang muncul pada saat ini, yakni ketika berusia 7 sampai 10 bulan,yaitu berupa bunyi yang dapat terlepas antara berbagai vokal dan konsonannya, namun belum ada bunyi yang dapat membedakan makna. Pada usia ini, ocehan bayi akan bertambah meningkat karenanya bayi mulai mendapatkan suku kata dan meniru-nirukan seperti contoh misalnya ucapan "bababa" ataupun "mamama". Dalam hal ini disebut dengan tahao kononikal. Tahap ketiga, pada umur sekitar 10 sampai 14 bulan, masa-masa seperti ini bayi mendapatkan langkah dan irama bahasa. Bayi akan belajar meniru dan memperaktekan apa yang ia dengar. Pada masa berusia 11 bulan anak masih dalam taraf belajar mengenal linkungannya sendiri atas dasar yang ia rasakan, laihat, dan di dengarnya. Ketika anak sedang menrasakan sesuatu tetapi anak tersebut belum mampu mengucapkannya, anak hanya akan memberikan atau memperlihatkan bahwa ia sedang senang atau tidak senang. Ketika anak memperlihatkan rasa tidak senang, ditunjukannya dengan rasa gelisah ataupun dengan cara menangis. Ketika anak senang ia mampu memperlihatkan kesenangannya, misalkan dengan tidak rewelnnya si anak, memperlihatkan gerakan positif, atau selalu memberikan respon ketika sedang diajak berbicara.

\section{Periode linguistik}

Kata infant bayi berasal dari bahasa infans yang dalam bahasa latinnya "tanpa ucapan" atau "tidak berbicara". Kata ini adalah kata yang pertama kali yang diucapkan seorang bayi dalam titik masa bayi akhir. Dalam masa seperti ini bayi mulai tampak perkembangan cara berbahasanya, bayi sudah mulai mampu mengembangkan kata-kata dalam bicara. Kata yang dimaksud disini yaitu kata yang telah berhubungan langsung dengan benda atau kegiatan tertentu. Misalnya mama, papa, baba dan baru mempelajari kata lainnya.

Perkembangan yang dialami saat seperti ini pada masa antara berumur 10 sampai 17 bulan. Perkembangan linguistik ini merupakan tahap kedua. Pada tahap awal ketika berusia sekitar 12 bulan anak menggunakan kata antara 3 sampai 6 kata. Tahap berikutnya pada 
usia 12 sampai 18 bulan, pada saat ini anak telah mampu menggunakan kata benda yang luas serta telah mampu menggunakan kosa-kosa kata yang terdiri antara 3 sampai dengan 50 kata.

Menurut berbagai pendapat musik klasik sangatlah berdampak positif terhadap rangsangan bayi. Karena reaksi yang diperoleh oleh musik dapat mengaktifkan berbagai sel-sel pada sistem yang ada pada saraf otonomi trhadap bayi, sehingga didalam tubuh bayi terdapat kekebalan yang sangat meningkat dan dapat merangsang pengeluaran serotonin dan endorphin.

Serotonin ialah zat kimia yang dapat memberikan suatu implus saraf yang ada diantara sel-sel saraf, atau dapat dinamakan neuron yang memiliki peranan dalam mencegah berbagai kecemasan, atau berbagai lainnya. Serotonim memiliki tingkat perubahan yang dapat menciptakan suasana yang rileks, dan tenang sehingga dapat memberikan peningkatan kualitas istirahat seperti tidur pada sibayi. ${ }^{7}$

Pada dasarnya manusia memiliki dua otak Yaitu, otak kanan dan otak kiri. Didalam otak kanan memiliki fungsi yang beridentik dengan kereativitas, khayalan, warna dan musik, emosi, dan menonjol terhadap hal-hal yang tidak dipikirkan secara mendetail. Sedangkan bagian otak kiri umumnya diidentikan kepada perbedaan, tulisan, bahasa, angka, dan logika.

Menjadikannya anak menjadi seorang yang cerdas, berkarakter, dan menjadi kreatif haruslah dilakukannya sejak dini. Diantaranya berbagai upaya yang dapat dilakukan salah satunya dengan seni. Musik klasik merupakan salah satu seni yang dapat berperan terhadap proses perkembangan tersebut. Pada usia bayi, bayi telah mampu menerima pelajaran yang dapat mempengaruhi perkembangan melalui otak. $^{8}$

\section{Cara Penerapan Musik Klasik Kepada Bayi}

Diberbagai penelitian penerapan yang dilakukan kepada bayi mengenai musik yakni diantaranya memberikan penerapan pendengaran musik terhadap bayi. Musik-musik tersebut dapat

${ }^{7}$ Sendi Maharani, Farida Sukowati, dan Elisa Ulfiana, "Pengaruh Kombinasi Pijat Bayi dengan Musik Klasik Mozart terhadap Berat Badan dan Kualitas Tidur Bayi Usia 3-6 Bulan," Jurnal Kebidanan 6, no. 13 (2017): 57-63.

${ }^{8}$ Nelva Rolina, "Memahami Psikologi Perkembangan Anak Bagi Pengembangan Aspek Seni Anak Usia Dini," Retrived from https://www. staff. uny. ac. id/sites/default/files/tmp/artikel-unkp4tksb. pdf, 2010. 
mempengaruhi perkembangan psikis dan intelektual bayi. Maka dengan cepat bayi akan memberikan respon terhadap musik yang mana sudah pernah diperdengarkan.

Berikut disajikan beberapa penelitian bagaimana peroses anak mengenali musik: 1) ketika ibu memperengarkan musik kepada bayi selama bulan terakhir kehamilannya, jabang bayi akan menjadi aktif bergerak; 2) pada saat pertama kalinya bayi itu tersenyum, musik lembut dengan nada yang tinggi akan membuatnya tenang; 3) ketika bayi beranjak berumur 4 hingga 6 bulan, bayi akan bereaksi mencari sumber musik mendengarkan dengan jeli; 4) suara penyanyi yang memiliki nada tinggi akan membawa efek yang menenangkan terhadap sibayi; 5) pada usia 4 sampai 6 bulan bayi akan memberikan respon terhada musik yang didengarkannya dengan jelas, berupa suatu gerakan-gerakan yang diulang-ulang; 6) usia sekitar 15 sampai 18 bulan mulai melakukan gerak-gerik pada irama musik tetapi masih dalam durasi yang pendek; 7) setelah bisa melakukan gerakangerakan dengan tepat, anak mulai menciptakan suara (seperti kokok ayam atau mengikik) merespon musik; 8) pada anak berusia 18 bulan anak sudah mulai bergerak suka menari-menari dengan kawan-kawan sebaya yang lainnya. Menari yang dimaksud disini ialah gerakan yang dilakukan anak secara sepontan karena rangsangan irama musik yang selalu didengarnya; 9) setelah anak sudah berumur 2 tahun anak sudah mulai memperlihatkan kemampuannya mendengarkan musik dengan durasi yang lebih lama dibandingkan bulan-bulan sebelumnya; 10) pada anak yang berumur 1 sampai 2 tahun anak mulai menirukan lagu anak-anak yang pernah ia dengar sebelumnya.

Musik klasik sangatlah memiliki keunggulan yang murni dan sangatlah sederhana akan bunyi-bunyi yang dimunculkannya. ${ }^{9}$ Orang tua khususnya bagi seorang ibu secara informal berperan penting untuk membimbing mereka memahami musik. Ketika anak mempelajari musik sama saja anak belajar tentang bahasa. ${ }^{10}$ Dari musiklah bayi memiliki banyak intraksi yang sangat menguntungkan bagi sibayi.

Dalam sebuah penelitian bahwa musik dapat memberikan suatu apapun. Didalam sebuah lagu terdapat sebuah kordinasi yang mana berpengaruh oleh tubuh. Musik dapat merefleksikan emosi terhadap

${ }^{9}$ Ike Dwi Permatasari, “Efektifitas Terapi Musik Klasik Mozart terhadap Penurunan Gejala Post Partum Blues” 2, no. 2 (2015): 9.

2014.

${ }^{10}$ Tetty Rachmi, Eko Purnomo, dan Agus Tatang Sopandi, "Keterampilan Musik dan Tari," 
diri seorang bayi, memberikan ketenangan jiwa, dan memberikan sebuah respon yang mana berupa ekspresi. ${ }^{11}$

Sebuah rangsangan dapat meberikan suatu perkembangan dan pertumbuhan yang dilakukan melalui musik. Untuk itu digunakannya suatu rangsangan guna agar bayi memiliki berbagai kemampuan dianaranya yani kemampuan dalam berfikir, kemampuan dalam motorik, dan kemampuan dalam berintraksi yang dialami sebagai seorang bayi.

Pengaruh alunan yang ada dalam musik memiliki pengaruh terhadap kecerdasan bayi. Kemampuan otak bayi akan memiliki stimulasi guna mempercepat suatu proses perkembangan yang ada pada otak bayi. Otak manusi terdapat sebuah mekanisme yang memberikan sinyal yang dapat mengenali musik. ${ }^{12}$

\section{Kesimpulan}

Musik ialah suatu ilmu pengetahuan dan seni yang didalamnya terdapat melodi yang terdiri dari ungkapan rasa dalam diri manusia dalam bentuk pemikiran yang menghasilkan nada-nada atau berupa bunyi yang dapat dikenal oleh diri sendiri maupun orang lain didalam lingkungan sehari-hari yang dirasakan.

Musik sangatlah berkesan sekali terhadap perkembangan manusia, yang mana didalamnya menimbulkan intraksi-intraksi yang dapat mempengaruhi bayi, baik bayi itu masih berada didalam kandungan maupun stelah lahirnya sibayi.

dalam sekema kognitif dapat aktif saat mendengar dan mempengaruhi bagaimana reaksi otak terhadap musik. Dilihat dari berbagai aspek kognitif dan aktifitas otak dapat diambil kesimpulan bahwa dari separuh dari otak manusia memiliki tugas untuk memperoses berbagai aspek pengalaman musik. Pada hal ini musik sangat dihubungkan dalam pengalaman emosi yang mana musik klasik sngatlah berhubungan dengan kecerdasan bayi.

Pada permulaan sensorimotor, pikiran bayi berdasarkan pada tindakan atau gerak-gerik fisiknya. Bayi melakukan sensorimotor

11 Nike Sari Oktavia, Supriadi Gandamiharja, dan leva B. Akbar, "Perbandingan efek musik klasik Mozart dan musik tradisional gamelan jawa terhadap pengurangan nyeri persalinan kala I fase aktif pada nulipara," Majalah Kedokteran Bandung 45, no. 4 (2013): 218-225.

12 alina Budi Arti, "Pengaruh Pemberian Musik Klasik pada Senam Bayi terhadap Kemampuan Motorik Kasar Bayi” (Universitas Muhammadiyah Surakarta, 2008). 
dengan secara kualitatif. Dalam hal ini bayi memiliki periode perkembangan yani periode pralinguistik dan periode linguistik.

Dalam perkembangan bayi terhadap musik klasik didalamnya sangat berperan sekali intraksi yang diperoleh oleh seorang bayi yang berpengaruh terhadap perkembangannya. Didalam sistem saraf yang ada pada manusia, otak memiliki dua bagian yaitu, otak kanan dan otak kiri yang mana memiliki fungsi yang berbeda-beda.

\section{Daftar Pustaka}

Arti, Alina Budi. "Pengaruh Pemberian Musik Klasik pada Senam Bayi terhadap Kemampuan Motorik Kasar Bayi." PhD Thesis, Universitas Muhammadiyah Surakarta, 2008.

Dariyo, Agoes. Psikologi Perkembangan Anak Tiga Tahun. Bandung: Pertama, PT Refika Aditama, 2007.

Hidaya, Saifaturrahmi. "Pengaruh Musik Klasik Terhadap Daya Tahan Konsentrasi dalam Belajar." PhD Thesis, Universitas Islam Negeri Sultan Syarif Kasim Riau, 2011.

Kurniawan, Novian Gangga. "Efektivitas Musik Klasik (Mozart) untuk Menurunkan Kejenuhan Belajar Siswa Kelas XI SMAN 4 Yogyakarta." Jurnal Riset Mahasiswa Bimbingan Dan Konseling 5, no. $\quad 7 \quad$ (12 $\quad$ Oktober http://journal.student.uny.ac.id/ojs/ojs/index.php/fipbk/article/view/ 4036.

Larasati, Dina Mutiah. "Pengaruh Terapi Musik terhadap Tingkat Kecemasan Sebelum Bertanding pada Atlet Futsal Putri Tim Muara Enim Unyted," 2017.

Maharani, Sendi, Farida Sukowati, dan Elisa Ulfiana. "Pengaruh Kombinasi Pijat Bayi dengan Musik Klasik Mozart terhadap Berat Badan dan Kualitas Tidur Bayi Usia 3-6 Bulan." Jurnal Kebidanan 6, no. 13 (2017): 57-63.

Ngalifah, Siti. "Pengaruh Musik Klasik terhadap Kecerdasan Emosional Anak di TK Kemala Bhayangkari 06 Glondong Tirtomartani Kalasan Sleman Yogyakarta Tahun Ajaran 2009/2010." Skripsi). Yogyakarta: UIN Sunan Kalijaga, dalam http://digilib. uin-suka. ac. id. Diakses pada 25 (2010).

Octora, Nelly, dan Setiasih. "Pengaruh Musik Klasik terhadap Emosi Bayi yang Kehadirannya Tidak Diharapkan oleh Orang Tuanya." Conference dipresentasikan pada Temu IImiah Nasional \& 
Kongres IX Himpsi, Surabaya, Januari 2004. http://repository.ubaya.ac.id/21413/.

Oktavia, Nike Sari, Supriadi Gandamiharja, dan leva B. Akbar. "Perbandingan efek musik klasik Mozart dan musik tradisional gamelan jawa terhadap pengurangan nyeri persalinan kala I fase aktif pada nulipara." Majalah Kedokteran Bandung 45, no. 4 (2013): 218-225.

Permatasari, Ike Dwi. "Efektifitas Terapi Musik Klasik Mozart terhadap Penurunan Gejala Post Partum Blues" 2, no. 2 (2015): 9.

Rachmi, Tetty, Eko Purnomo, dan Agus Tatang Sopandi. "Keterampilan Musik dan Tari," 2014.

Rolina, Nelva. "Memahami Psikologi Perkembangan Anak Bagi Pengembangan Aspek Seni Anak Usia Dini." Retrived from https://www. staff. uny. ac. id/sites/default/files/tmp/artikel-unkp4tksb. pdf, 2010. 
